\title{
The pros and cons of deconstructing Bakhtin: A reflection on Boris Groys
}

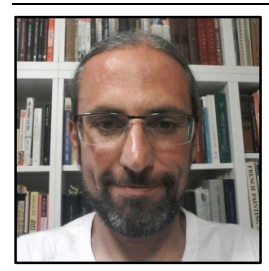

\author{
Sergeiy Sandler \\ Independent scholar, Israel
}

Sergeiy Sandler is a scholar and translator (into English and Hebrew) of Mikhail Bakhtin's works. He is the author of multiple articles on Bakhtin's philosophy, as well as of studies promulgating a Bakhtininspired approach to linguistics and the philosophy of language.

\section{$\cos 050$}

In the summer of 1989, the heated debate around the theories of French poststructuralist thinkers (Michel Foucault, Jacques Derrida, and others) and their American followers was all the rage in many intellectual circles. It is as a contribution to this debate that Boris Groys originally published the article, which has now been brought to us in English translation on the (virtual) pages of the Dialogic Pedagogy Journal. The contribution was quite sophisticated-a critique of some central ideas of poststructuralism (rejecting the notion of the subject, the "death of the author") using poststructuralism's own methods of genealogy and deconstruction. More specifically, Groys offered a critique of poststructuralism carried out in the form of a deconstructive reading of one of poststructuralism's "ancestors", and his choice of "ancestor" was Mikhail Bakhtin. This, of course, required reading Bakhtin's work as poststructuralism avant la lettre-a strained interpretative exercise to say the least. ${ }^{1}$ But strained interpretations can sometimes nevertheless yield interesting results. And so it happened that Groys' article became a somewhat scandalous classic in the field of Bakhtin scholarship.

Within the context of Bakhtin scholarship, Groys' article is a mixed bag, the way strained interpretations are prone to be. As we shall see below, Groys chanced upon one truly valuable insight when, in the last paragraphs of his piece, he analyzed Bakhtin's notion of carnival in Nietzschean terms, and more specifically as a sort of self-sacrifice. Beyond that, Groys' reading of Bakhtin is a deconstruction, and at its best, it can do what a good deconstruction does: expose latent tensions and potential contradictions in the deconstructed text, pose new questions for later research into it, and point to weaknesses in more "traditional" readings. In its weaker spots, though, Groys' reading fails even as a deconstruction: it uncritically embodies some problematic practices in reading Bakhtin's works, and at times (especially where Groys tries to force on Bakhtin some poststructuralist ideas about authorship) he deteriorates into utter incoherence and does violence to the texts he claims to interpret.

\footnotetext{
${ }^{1}$ Though, to be fair, poststructuralist appropriations of Bakhtin—now strongly discredited—were still a relatively common practice in the 1980s.
} 
In what follows, I will discuss each of these pros and cons of Groys' reading of Bakhtin. In the process, I will also offer my own reading of Bakhtin's philosophy, and particularly of the role that the notion of carnival plays within it.

\section{The things you could get away with back in 1989}

I will spend most of my time discussing the serious challenges Groys' article posed, but at its base, it offers a seriously flawed reading of Bakhtin. So, before I get into deeper waters, let me briefly note some of that article's most obvious weaknesses.

The primary problem with Groys' article lies at the heart of its main argument: Groys wants his criticism of Bakhtin to reflect on poststructuralism, and in the process uncritically reads poststructuralism into Bakhtin.

Now, it is true that Groys only explicitly speaks about Bakhtin as an important figure in the formation of poststructuralism, not, at first blush, as a direct carrier of postmodernist philosophical ideas. It is also true that Bakhtin's ideas were influential, up to a point, within French postmodernism, especially as filtered through the readings given to them by Julia Kristeva (1986) and Tzvetan Todorov (1984). Back in 1989, that Kristeva/Todorov version of Bakhtin was still relatively fresh. Today, however, it is easily recognizable as one-sided. It speaks of intertextuality, but not of intersubjectivity, of a dialogic principle detached from actual persons engaged in dialogue. Bakhtin's principled personalism-the clear and consistent cornerstone of his thought-is painted over, and it is painted over, one could argue, precisely because it would not have been given a very warm welcome in the sort of milieu Kristeva and Todorov were writing for. ${ }^{2}$

Groys' reading of Bakhtin suffers from all the flaws of the Kristeva/Todorov version, and then adds some. Take his claim that "Bakhtin welcomes the carnivalesque pathos of the 'final death' of everything individual". If you are wondering where exactly does Bakhtin-who famously wrote "Nothing is absolutely dead: every meaning will have its festival of resurrection" (Bakhtin 1986e, 170; translation modified)-welcome such a pathos, well, you are right to wonder. The phrase "final death" (okonchatel'naia smert'), which Groys places between quotation marks, suggesting it is a quote, only appears in Bakhtin's extant writings once, in notes from the early 1960s (Bakhtin 2002, 349). The context is an analysis of Dostoevsky's short story "Bobok", and the reference is to the "final death" of that story's characters (who are already dead, but not quite finally). No ruminations about "everything individual" are implied. Moreover, Groys could not possibly have been citing this text-it was not published until 2002. A more likely option is to read this phrase as a loose quotation of a passage from "Forms of time and the chronotope in the novel" (Bakhtin 1981c, 220), where Bakhtin writes Lucian's satires put to "ultimate, comic death" the gods of Greek and Roman myth. Only the gods are not mentioned in that passage as some sort of a metaphor on individuality, "comic death" is not quite the same as death, and that comic death is said to be "ultimate" in the sense of being long-overdue.

In short, Groys ascribes to Bakhtin a position on the final death of individuality that directly contradicts anything Bakhtin had ever written about finality, death, or individuality, and he has zero evidence to support his interpretation. Groys' attempt to coopt Bakhtin's notion of polyphony into his reading is no more convincing:

\footnotetext{
${ }^{2}$ The publication history of Bakhtin's works accommodated such readings to some extent. Bakhtin's earliest and latest works, in which his personalism was on starkest display, were mostly published and translated late in the day, from 1979 on, when Kristeva's and Todorov's main contributions were long published.
} 
This truth is, according to Bakhtin, incarnated in the "carnivalesque", or, in other words, "polyphonic" novel. All the voices, in Bakhtin's opinion, have the right to be heard-but only within the context of a whole, totalitarian, all-absorbing novel. Such a novel, in fact, cannot even have an author, because an author should exist outside of the novel-which, according to Bakhtin, is not allowed to anyone. A "polyphonic" novel tautologically reproduces its own total, always proportional to itself, polyphony-just like the carnival always reproduces its own total carnivalesque properties. Consequently, Bakhtin de facto denies the existence of multiple novels with different authors and he accepts only one differentiation in the space of the novel genre,--novels are either monologic and are, therefore, dismissed as too individualistic, or polyphonic, which means they reproduce each other as they reproduce polyphony itself, making, therefore, their author a hypothetical, fictitious figure. For Bakhtin, "other" is always someone inside a novel, and never can it be someone outside of the novel.

The views about authorship, which Groys attacks here, would be familiar to any reader of Roland Barthes (1977) and Michel Foucault (1988), but latching them onto Bakhtin takes some nerve. Groys is beating up a straw man, and a shabbily designed one at that. One can go over this paragraph claim by claim and show Bakhtin never said anything of the sort.

To begin with, no, "polyphonic" and "carnivalesque" are not quite the same thing. In Problems of Dostoevsky's Poetics, Bakhtin credits Dostoevsky with the creation of the polyphonic novel (Bakhtin 1984a, 5-46), while many earlier authors are said to have worked firmly within the carnivalesque tradition. Groys also gets his chronology wrong here, by the way. Bakhtin first brings the notion of carnival to bear on Dostoevsky's work in notes from the mid-1940s (e.g., Bakhtin 2014, 525, 526, 535), and it's not until the early 1960s, long after the end of Stalin's purges, that Bakhtin attempts to integrate his notion of carnival into his book on polyphony. Groys (implicitly) misplaces carnival back into the first edition of Bakhtin's book on Dostoevsky, published in 1929, where it is distinctly absent.

I sincerely have no clue where Groys could find any support in Bakhtin's writings to the idea that voices have the right to be heard only in the context of the polyphonic novel, or that this novel is meant to be "all-absorbing". I also couldn't find any place where Bakhtin suggests the polyphonic novel cannot have an author, or that existing outside the novel is "not allowed to anyone". Locating passages where Bakhtin claims the exact opposite, on the other hand, is not particularly difficult. Bakhtin's book on Dostoevsky begins with a sustained discussion of Dostoevsky's distinctive achievement as a creator (khudozhnik), of how earlier studies of his novels failed to grasp the guiding principles of his work as an author, focusing instead on the views espoused by his characters (Bakhtin 1984a, 5-46). And as for existing outside the novel, I need only recall one central Bakhtinian principle, running through all aspects and periods of his work (see, e.g., Bakhtin 1990, 212; Bakhtin 1986b, 7)—the principle of outsidedness (vnenakhodimost'). Of course people exist outside the novel; otherwise the novel would be meaningless, unreadable, impossible to evaluate. Evaluation, for Bakhtin, can only come from outside.

What Groys seems to be aiming at in these comments is the structuralist view, enthusiastically adopted by the poststructuralists, that the author of a text should only be considered as a function of the text itself, not as a real person in the outside world. In Soviet literary scholarship, a parallel view was represented by Viktor Vinogradov's doctrine on the "image of the author" (obraz avtora) as contained in the literary work. Bakhtin, however, made a point of arguing against this doctrine, repeatedly (e.g., Bakhtin 1986d, 109-10, 116; Bakhtin 1986a, 148; Bakhtin 1986e, 160-61; and see Gogotishvili 1996, $600,606,629-31$ ), on the grounds that this would involve a form of direct authorial presence within the author's work, depriving the author of her rightful position outside the work (or "tangential" to it, as he puts 
it in Bakhtin 1981c, 254-55). Bakhtin does praise Dostoevsky's choice to avoid using the benefits of his outsidedness against his characters (e.g., Bakhtin 1984a, 69-75), but that is hardly the same as denying the author exists at all, or that the author exists outside the work. ${ }^{3}$

The claim that all polyphonic novels tautologically reproduce one another and that therefore all polyphonic novels are de facto the same is pure fantasy. Groys makes no attempt to ground it in textual evidence, and it's not that he'd find any such evidence if he tried. Finally, as we already saw, the other for Bakhtin is first and foremost precisely someone outside the novel, and only by extension also someone inside it. ${ }^{4}$

To reiterate, much of what Groys is doing could still pass as par-for-the-course in Bakhtin scholarship at the time he was writing. A reading of Bakhtin limited to his two monographs (and perhaps also the four essays on the novel gathered in Bakhtin 1981d), flatly ignoring Bakhtin's early and late writings and working notes, was still acceptable back then. Moreover, many of these writings were either still unpublished or published only very recently, in perhaps not the most accessible editions, at the time. It was also still quite common in the 1980 s to see readings of Bakhtin as a structuralist, or poststructuralist, and indeed also as a Marxist. When Groys wrote that Bakhtin was "influenced by Marx and Freud", without any caveats, as if this were a simple statement of fact, it looked not as preposterous back in 1989 as it does now. ${ }^{5}$ But even making an allowance for when Groys was writing, the truth has to be said: as an interpretation of Bakhtin, Groys' article simply does not hold water.

\section{Totalitarian carnival?}

Another sense in which Groys' reading of Bakhtin is typical of the 1980s is the ease with which Bakhtin's work is brought to bear on the political conditions under which he was writing. The gist of most such readings is briefly and poignantly summarized by Groys early in his essay: Bakhtin is said to be a "consistently anti-authoritarian thinker", whose notions of polyphony and carnival directly (albeit allegorically) repudiate the Stalinist regime they were conceived under. And while nobody, not even Groys, thinks Bakhtin was a fan of Stalin, there really is very little evidence to read into Bakhtin's notions any commentary clearly touching on contemporary political realities. Groys effectively offers a reductio ad absurdum of such readings by showing there are many ways to read the purported "allegories" in Bakhtin's writings.

But, by the same token, Groys' own reading exemplifies what's wrong with the methods applied in the work he criticizes, and, indeed, in many other attempts to apply Bakhtin's concepts, especially that of carnival, to any number of social and aesthetic phenomena. In a nutshell, the problem with all these readings is that they consider some aesthetic "symptoms" of carnival (or some other Bakhtinian term) as sufficient for a full "diagnosis", while the philosophical essence of the concept is left out of the discussion. And while usually this flaw in the argument is concealed by the generally-agreeable nature of the

\footnotetext{
${ }^{3}$ Moreover, Bakhtin's draft notes written when he was working on the second edition of his book on Dostoevsky (Bakhtin 2002, 303, $314,316,319-20)$, indicate he was explicitly concerned with the nature of the author's outsidedness in a polyphonic novel. He reiterates the view that an author is always located outside the work, and finds concrete expressions for this outsidedness in Dostoevsky's writing (for instance, in his use of double-voiced discourse), while distinguishing these forms of outsidedness from simpler, monological forms.

${ }^{4}$ One can be more specific, noting the prototype for all forms of the other in Bakhtin's philosophy is "absolute otherness" (Bakhtin 1990,144 ), i.e., God (and see Erdinast-Vulcan 2013, 33-36). The existence of a religious dimension in Bakhtin's work (a dimension that is explicitly stated in several of his works, e.g., Bakhtin 1993, 16; Bakhtin 1990, 138-50; Bakhtin 2001, 207-9, 219-21; Bakhtin 1996, 7-10; and see Coates 1998) entirely contradicts Groys' attempt to paint Bakhtin as a denier of all things spiritual and nonmaterial. But, to be fair, very few of the explicit religious references in Bakhtin's writings were allowed into print in Soviet times, so Groys would not have had access to them back in 1989.

${ }^{5}$ Besides, as we shall see, Groys was much closer to the mark putting Nietzsche on the same list.
} 
phenomena claimed to be carnivalesque, Groys' idea that carnival is really a form of totalitarianism can make the problem much easier to spot.

Groys has two sorts of arguments for his claim about the totalitarian nature of carnival. I will deal with the more substantial of the two-grounded in the apparently all-encompassing nature of carnivallater on. But there is also the more superficial kind of argument, where Groys claims to find carnivalesque motifs in the practices of Stalinist terror: laughter at show trials, "crownings and dethronings" of party officials, even Stalin's preference for the film "Volga Volga" (which Groys finds to be "purely carnivalesque", without explaining exactly why).

The problem is that by this sort of criteria, virtually anything can be declared "carnivalesque". Groys records the presence of some features Bakhtin associated with carnival (laughter, on some occasions, promotion and then persecution of officials), but makes no mention of others (overabundance of food and drink, images connecting the "topographies" of body and cosmos, especially the nether parts of the human body with the nethers of the Earth, leveling social hierarchies). For the features he does mention, the resemblance could be quite superficial. Notably, no crowning and dethroning touched the very top of the hierarchy (Stalin himself), while a "carnival king" is meant to stand for the highest authority in the state.

With a bit more effort, Groys could have achieved better resemblance. Soviet propaganda definitely claimed great material plenty existed in the country, and claimed the USSR was a place of freedom and equality. Indeed, old social hierarchies were upended by the new regime (only to be replaced by new ones, of course). But this entire approach misses the point. Carnival is not defined by a checklist of external features. It is rather a philosophical attitude, linked to ethical ideals and an elaborate development of aesthetic means for reproducing subjectivity and freedom in a literary image-but I'm getting ahead of myself (and of what Groys could have known about Bakhtin's philosophy at the time of writing). I will come back to the roots of carnival in Bakhtin's philosophy later on. However, the main ethical commitments Bakhtin invested his notion of carnival with should have been apparent to Groys, even in 1989.

Above all, carnival laughter, for Bakhtin, overcomes fear (of all powers human, natural, and supernatural). This is evident from several passages in Bakhtin's book on Rabelais. Here are just a few examples:

[T]he images of folk culture are absolutely fearless and communicate this fearlessness to all. This is also true of Renaissance literature. The high point of this spirit is reached in Rabelais' novel; here fear is destroyed at its very origin and everything is turned into gaiety. It is the most fearless book in world literature (Bakhtin 1984b, 39).

[M]edieval and Renaissance grotesque, filled with the spirit of carnival, liberates the world from all that is dark and terrifying: it takes away all fears and is therefore completely gay and bright. All that was frightening in ordinary life is turned into amusing or ludicrous monstrosities.

\footnotetext{
${ }^{6}$ The truth has to be said that Bakhtin himself could often be overly sketchy when counting phenomena and literary pieces as belonging to the carnival tradition. But then, Bakhtin's task was different: his aim was to establish a notion (carnival, menippean satire, etc.), make it tangible to readers. This required bringing in a vast amount of material and molding a picture out of that. Bakhtin was not aiming to deduce that this or that piece is carnivalesque, but rather was trying to induce a coherent vision of carnival out of a wide variety of examples. One can dispute whether some of these examples are good, but Bakhtin's central thesis does not hang on any one example. That's not the case with Groys' claim that Stalinist terror was carnivalesque, in Bakhtin's sense, which is quite central to his argument in the article.
} 


\section{The pros and cons of deconstructing Bakhtin: A reflection on Boris Groys}

Sergeiy Sandler

Fear is the extreme expression of narrow-minded and stupid seriousness, which is defeated by laughter [...].Complete liberty is possible only in the completely fearless world (Bakhtin 1984b, 47).

It was the victory of laughter over fear that most impressed medieval man. It was not only a victory over mystic terror of God, but also a victory over the awe inspired by the forces of nature, and most of all over the oppression and guilt related to all that was consecrated and forbidden ("mana" and "taboo"). It was the defeat of divine and human power, of authoritarian commandments and prohibitions, of death and punishment after death, hell and all that is more terrifying than the earth itself (Bakhtin 1984b, 90-91).

In the whole of the world and of the people there is no room for fear. For fear can only enter a part that has been separated from the whole, the dying link torn from the link that is born. The whole of the people and of the world is triumphantly gay and fearless. This whole speaks in all carnival images; it reigns in the very atmosphere of this feast, making everyone participate in this awareness (Bakhtin 1984b, 256).

Stalinist terror, as the name suggests, was by no means about overcoming fear.

Needless to say, Groys also brings no evidence for what Bakhtin terms "ambivalence" in Stalinism: invective is not conjoined with praise, and death does not imply rebirth. The image of laughter at a trial at least allows conjuring up some semblance of a third defining feature of carnival imageryliminality. One could describe the defendant as standing on the limit (possibly on the limit between life and death). But Groys does not make this link (at least not explicitly), nor does he claim any "ultimate questions" (Bakhtin 1984a, 115) of ethical and philosophical import came up at those occasions. At best, Stalinism could lay claim on declaring the fearless leveling of all hierarchies, on abundance and plenty, together with philosophical depth at show trials, but that would mean taking it at its official, censorshipbound word-exactly what Bakhtin claimed was antithetical to carnival joy and laughter (Bakhtin 2014, $524,528)^{7}$

Fearlessness, ambivalence, and liminality are not just three more items on a laundry list of carnivalesque features (on par with laughter, food, scatology, etc.). They describe not what carnival imagery looks like, but what it means, and if the meaning ain't there, it ain't carnival, even if it looks a bit similar to true carnivalesque images in some respects. ${ }^{8}$ Moreover, there is arguably an even higher philosophical level at which carnival is truly defined, but, again, that's for later on.

The challenge Groys poses to Bakhtin's notion of carnival is not really that shallow, though. It's not that Groys ignores what carnival means. Rather, Groys assigns a meaning to carnival that is different from the one Bakhtin claims for it (the sort of things deconstructive readings can take the license to do). For Groys, carnival is totalitarian not because people laughed at trials in Stalin's USSR, but because in its

\footnotetext{
${ }_{8}^{7}$ Although, again, this is a point Bakhtin makes explicitly in texts first published after 1989.

${ }^{8}$ To be more precise, the "external" features are defined by Bakhtin in such a way that they already carry the meaning of carnival within them. So, for example, laughter for Bakhtin is no accidental feature of carnival. Quite on the contrary, he continuously stresses it as a defining feature of carnivalesque culture as such (calling it smekhovaia kul'tura, "culture of laughter"). But then, when Bakhtin speaks of laughter, he does not have the sound of giggles in mind. Purely scornful laughter is a one-sided exemplar of the phenomenon, in which the positive aspect has been lost or misunderstood, while such a somber piece as Boethius' Consolations of Philosophy is, per Bakhtin, full of "reduced laughter" (Bakhtin 1984a, 114, 134). Why? Because it is a discussion of "ultimate questions" on the verge of death, inducing a fearless attitude toward all powers. Bakhtin's concept of laughter is defined by what that laugher means, not by what it looks or sounds like, just like his notion of carnival is.
} 
very essence, carnival is all about destroying human individuality, swallowing the individual into the crowd, into the folk:

Simply put, Bakhtin's carnival is horrible-God forbid being part of it. There is no place for democracy in it-nobody is given the democratic right to avoid the total carnival duty, to abscond the carnival, to stay away from it.

This alternative essence of carnival is also what all of the misreadings and dubious claims in Groys' article, which we discussed above, stem from and are geared toward.

Groys does capture a certain uneasiness some of Rabelais' passages (and Bakhtin's descriptions of them), ${ }^{9}$ arouse in many modern readers. Our individualistic psyches demure at the thought of a festivity everyone takes part in. We are quick to sense an implied threat of coercion. The many dismemberments of characters standing in the way in Rabelais' novel-think especially of the "tragic farce" story on François Villon and the sorry fate of the sacristan, who tried to stand in the way of the carnival play, recounted in Chapter 13 of Rabelais' Fourth Book (see Bakhtin 1984b, 263-64)-seem to confirm our worst suspicions.

Bakhtin himself was aware of such a possible reading of Rabelais, and made a point of rejecting it:

[T]ime has transformed old truth and authority into a Mardi Gras dummy, a comic monster that the laughing crowd rends to pieces in the marketplace.

Kind master Rabelais deals with these dummies pitilessly, cruelly, but merrily. Actually, it is gay time itself in whose name and with whose voice the master speaks. Rabelais does not torture living persons. Let them go, but first of all let them remove their royal robes and pompous academic gowns of the Sorbonne in which they masquerade as heralds of divine truths. Rabelais is even disposed to grant them a little hut in the backyard and a mortar to crush onions for "greensauce", as he did King Anarchus. Or he may give them some cloth for a new pair of trousers, or a soup tureen, a sausage, or firewood such as he offered Master Janotus de Bragmardo (Bakhtin 1984b, 213).

One may or may not agree with Bakhtin's interpretation of Rabelais in this passage, but the important point for our purposes is not about Rabelais, but about Bakhtin and how he defined his notion of carnival. Violence to persons, to individuals, is not part of how Bakhtin wanted his conept to be understood, and wherever such violence appears in texts he analyzes, he gives it an allegorical reading. ${ }^{10}$

More broadly, precisely what Groys deems to be the essence of carnival-the elimination of the individual in favor of the collective-is a position Bakhtin has always been at pains to renounce and argue against. The notion of a collective subject is a constant target of polemic in Bakhtin's writings (e.g., Bakhtin 1993, 66-68; Bakhtin 1986a, 147). The uniform rational subject of Kantian philosophy fares hardly better. ${ }^{11}$ It is true that Bakhtin also rejects the Cartesian version of individualism and argues for the

\footnotetext{
${ }^{9}$ Arguably, Groys' critique of carnival as totalitarian works much better as an interpretation of Rabelais than as an interpretation of Bakhtin.

${ }^{10}$ To be more precise, violence against other persons is excluded from Bakhtin's notion of carnival. We will later see that, in one sense, carnival imagery in general can be understood as an externalized image of the self and the violent aspects of carnival practices turn out, paradoxically, to be a form of self-mortification.

${ }^{11}$ On Bakhtin's complex attitude toward Kant and Kantianism, see Sandler (2015); Erdinast-Vulcan and Sandler (2015).
} 
constitution of the subject by and through other subjects, ${ }^{12}$ but such dependence on others is, for Bakhtin, the way in which individuals can truly and fully become individual. Authorship and creativity is achieved in truth when the author absorbs and learns to manipulate, speak through, other voices (e.g., Bakhtin 1981a, 293-94). For Bakhtin, intersubjectivity does not contradict individuality. On the contrary, it enables and enhances it.

\section{The (uneasy) place of carnival in Bakhtin's philosophy}

And yet, in his one-sided way, Groys was on to something. In writings on carnival, and in the book on Rabelais in particular, Bakhtin does speak of an "ancestral body" (rodovoe telo; Bakhtin 1984b, $19,29,322-24,367)$ that transcends the life and death of an individual human being. This tension between some characteristics of carnival imagery and the consistent philosophical personalism we find in Bakhtin's writings, has been frequently discussed in Bakhtin scholarship (see, e.g., Morson and Emerson 1990; Wall 1998), and Groys' article was among the first to highlight it. ${ }^{13}$

This tension is not easy to explain away. It is not merely a matter of chronology-while carnival as a major theme in Bakhtin's work is largely concentrated within a relatively short time span (roughly 1938-1950), and personalism is more prominent in other periods (the 1920s, 1960s, and 1970s), there is also a good deal of overlap between these themes in particular texts (most notably in the 2nd edition of Bakhtin's book on Dostoevsky, Bakhtin 1984a, 101-80, but also in other works, e.g., in "Response to a Question from the Novy Mir Editorial Staff", Bakhtin 1986b, 5-7). Needless to say, Groys' "solution" to this problem - the claim that Bakhtin embraced totalitarianism and rejected all forms of individuality—cannot be taken seriously either, as it flatly ignores central elements of Bakhtin's thought.

To explain, and perhaps resolve, this tension in Bakhtin's philosophy, one should delve deeper into its development, locate the philosophical problem to which Bakhtin sought a solution in his notion of carnival. I would like to use the opportunity to briefly sketch my own positon on the matter (for a more detailed discussion, see Sandler 2016).

To understand where Bakhtin is coming from, we should first of all examine his early philosophical works (incomplete as they are), Toward a Philosophy of the Act (Bakhtin 1993) and "Author and Hero in Aesthetic Activity" (Bakhtin 1990), written, most probably, in the early 1920s. Toward a Philosophy of the Act, in particular, stands at the very heart of Bakhtin's philosophical project. It contains what we would today call an existentialist argument for the philosophical primacy of subjective action and experience-which Bakhtin refers to as an act or a deed ${ }^{14}$ - over objective, scientifically valid, realities. ${ }^{15}$

To illustrate what Bakhtin means by that, let us consider a very simplified analysis of one of his own examples (see Bakhtin 1993, 65-73; Bakhtin 1990, 211-22)-from a poem by Alexandr Pushkin. In that poem, the narrator recounts his parting from a woman he was in love with. if we read this as a crudely autobiographical reference (which we will assume for simplicity's sake), the man here is Pushkin

\footnotetext{
${ }^{12}$ This, in itself, is in fact a common feature of German philosophy from Hegel on. Bakhtin's innovation here is that he does not view this as a step toward the eventual unification of self and other in a collective subject (see Sandler 2012a; Sandler 2015, 180).

${ }^{13}$ Though, to be more precise, Groys does not really notice any tension. He seems quite unaware of Bakhtin's personalism.

14 "Deed" is a more accurate translation of the Russian postupok in this context, and I will be using it exclusively below, despite the fact that the published English translation of this work has "act", not "deed", in its title (which is, in any case, not Bakhtin's original, and lost, title for the treatise).

${ }_{15}$ This argument closely resembles, and is directly influenced by, a central argument advanced by Søren Kierkegaard (1992). For more on Bakhtin and Kierkegaard, see, e.g., Fryszman (1996) and Schittsova (1999), and, more specifically in this context, see Sandler (2011; 2012a; 2012b, 229-33).
} 
himself, while his lover is Amalia Riznich, an Italian, and the event described is her sailing back to Italy (never to return) from the port of Odessa in 1824.

Now, objectively speaking, Riznich's upcoming journey was one event-that of Riznich traveling from Russia to Italy on a certain trajectory in space and time. We can draw that journey on a map. But subjectively speaking, that journey is (at least) two different deeds: from Riznich's perspective, she is going home; from Pushkin's-she is going away and abroad. Moreover, if we now focus just on Riznich's perspective, her journey for her is no mere line on a map either. She does not experience it as such a line, and, more generally, she does not experience space as a neutral frame viewed from nowhere-inparticular. She is always situated within space, focusing her sight on some regions of it, not others (she does not see what's behind her back, or what's many miles away). Moreover, space and time for her are imbued with evaluations, "tones", or "intonations" (Bakhtin 1993, 32-34). For one thing, there is one region of space that is the destination of her journey, and in the context of the journey itself as a deed, it has privileged status. Space is ordered into a hierarchy of places closer to the destination and farther from it. Space is also ordered, for each of us, into places near and far, in front of us and behind us, etc. Time is divided into past, present and future. All these categories are meaningful subjectively, to individual human beings, but not objectively. Space and time in the abstract have no future and no past, no near and no far, no home and no abroad. We can define such terms in relation to any arbitrary point in space and time, at which we would potentially place a person answering this or that description. But that hypothetical person is not actually there to see and evaluate anything, and actually standing there, doing and experiencing and evaluating, is beyond anything you can capture by describing a hypothetical person, placed hypothetically at some spatio-temporal coordinates (e.g., Bakhtin 1993, 28-29; for more details, see Sandler 2012b, 229-33; Sandler 2013, 154-55). No amount of objectively correct information about the world entails actual human deeds and experiences.

The barrier between the deed and objective reality is only insurmountable in one direction, though. Maps and lines on them are part of the lived experience of many people, travelers included. The same is true for other abstract theoretical representations and for all sorts of objectively correct information about the objective reality we share (Bakhtin 1993, 2-3). What Bakhtin disputes in Toward a Philosophy of the Act is not the objectivity or reality of the real and objective world (e.g., Bakhtin 1993, 910). He rather argues about the philosophical order of priorities. A philosophy that takes objective reality to be the only truly real world while people's deeds are treated as merely subjective (Bakhtin refers to such positions as "theoretism"), would have no possible way to account for the actuality of my own firstperson experiences and deeds. A philosophy that takes people's deeds to be ultimately real, can account for all things objective as abstractions we make from our own experiences, and those of others (this implies people can communicate, and more broadly implies intersubjectivity in a strong sense-we'll get to that in a moment). Thus, Bakhtin concludes, it is the multiplicity of human deeds that underlies the unity of the objective world, not the other way around.

So far, the thrust of Bakhtin's argument is diametrically opposed to what Groys finds in his texts (although, of course, Groys shows no evidence of having been familiar with Bakhtin's early philosophical writings). Groys "credits" Bakhtin with the desire to eliminate all individuality. But it is precisely the individuality of persons that Bakhtin argues from and for when he claims deeds-the worlds constituted by persons' lived first-person experiences, actions, and evaluations-take philosophical precedence over the objective reality that can be abstracted from them. The uniqueness (edinstvennost') ${ }^{16}$ of actual human persons and their deeds is "heavier", Bakhtin tells us, than the unity of the objective world (Bakhtin 1993, 8).

\footnotetext{
${ }^{16}$ See Sandler $(2015,175-77)$ for more on the origins and use of the term "uniqueness" in Bakhtin's early works.
} 
But this is only one half of Bakhtin's two-step move. A person, for Bakhtin, is no self-sufficient Cartesian subject. In the world constituted by my deeds, I can see many other people, but there is no room in it for me, not, that is, as an entity among other entities. In my deed, I come out (iskhozhu) of myself and come upon (nakhozhu) others (Bakhtin 1993, 73-74), but I cannot locate myself. ${ }^{17}$ To become a subject, to obtain a reflection of myself in the world, Bakhtin tells us, it is not enough for me to simply look in the mirror. In a mirror, I see an external image of my body that necessarily fails to merge with my inner sensation of myself into a single coherent image (see especially Bakhtin 1990, 27-35, but also Bakhtin 1986b, 7, and Bakhtin 1996, 71; for English translations of the latter reference, see Emerson 2000,25 , or Nikulin 2011,61 ). There is only one kind of source from which I can obtain a true image of myself. This source is other people (and, eventually, God). A mirror would not do. A good portrait (and not a self-portrait) might (Bakhtin 1990, 34-35). This also means, for Bakhtin, that only in giving up on my own presence in my world, only by accepting others' authority over my image, do I get to receive such an image of myself as a graceful gift from the other.

We have, by now, entered deep into the sphere of Bakhtin's aesthetics. But this aesthetics, more than other aspects of Bakhtin's philosophy, went through several stages of development. The earliest stage is expounded in some detail in the unfinished treatise "Author and Hero in Aesthetic Activity" (Bakhtin 1990), written around 1923/4. At the center of this early aesthetics we find an emphasis on the act of completion (or "consummation", in the published English translation; the Russian is zavershenie) of the literary character (the "hero") by an author, which is, at the same time, also the completion of me by an other, of a person by God. This completion is carried out from an external position, outside the person being completed. This external vantage point allows the author/other to:

collect the hero and his life and to complete him to the point where he forms a whole by supplying all those moments which are inaccessible to the hero himself from within himself (such as a full outward image, an exterior, a background behind his back, his relation to the event of death and the absolute future, etc.) (Bakhtin 1990, 14)

It is through this act of grace that I may obtain proper access to an image of myself as a whole.

People familiar mostly with Bakhtin's later works will find in this description an eerie combination of familiar and strange themes. The crucial importance of outsidedness (vnenakhodimost') for evaluation and for authorship will remain, as we have already seen, a staple of Bakhtin's thought for his entire life, as will the notion that I depend on others for any true self-assessment and self-image, and the (sometimes thinly veiled and sometimes explicit) promise of immortality in the minds of others (and of God), but not in my own spirit (on which see below). But an author looking behind her character's back, from after the time of his death, is supposed to be anathema to the Bakhtin most people know. This indeed reflects a reversal in Bakhtin's position, or better, in his focus, but one that aims to extend and further develop his core philosophical principles, not to walk them back.

Bakhtin's first major publication-the 1929 edition of his book on Dostoevsky-credits Dostoevsky with the creation of a new literary form, the polyphonic novel. In the polyphonic novel, central characters are self-conscious, and actively resist any attempt to comprehensively describe them, bring them to completion. Dostoevsky, the author, does not supply us with a view of what is behind their backs,

\footnotetext{
${ }^{17}$ So, what I am thus missing is exactly the ability Rene Descartes (1996) used to define his notion of a subject-the ability (the naïve ability, Bakhtin would say) to see myself. Anti-Cartesianism is the one thing that Bakhtin and the French poststructuralists really do have in common, and it is this anti-Cartesianism that Groys seems to conflate with anti-individualism.
} 
nor with totalizing reflections on their lives and deaths from a vantage point forever in their future (e.g., Bakhtin 1984a, 69-75).

Now, all the elements in this description of Dostoevsky's works already appear in the earlier "Author and hero" (Bakhtin 1990, 19-21, 146). ${ }^{18}$ But there is a crucial difference in Bakhtin's evaluation of these features of Dostoevsky's writing. In his earlier work, Bakhtin interprets them as a sign of failureDostoevsky fails to attain completion for his characters because he fails to distance himself from them (they are, on this early account, essentially autobiographical). The resulting literary works lack proper aesthetic form. But by 1929, those same features mark Dostoevsky's true greatness as a writer (Bakhtin uses the Russian word khudozhnik, literally "painter", which specifically implies the creation of aesthetic form, to refer to Dostoevsky as the creator of the polyphonic novel, when he states his main thesis on the book's first pages-see Bakhtin 1984a, 5). His characters are no longer seen as autobiographical but are explicitly others with respect to the author (Bakhtin 1984a, 7). Dostoevsky himself is no longer said to have failed to attain completion for his characters, but rather to have deliberately refrained, on ethical grounds, from abusing his authorial perspective by completing them (Bakhtin 1984a, 69-75 et passim). ${ }^{19}$

Like the hero of Bakhtin's early aesthetics, Dostoevsky's characters are granted a form (or rather, a voice) by the other/author. Unlike the predetermined hero of "Author and Hero" (see Bakhtin 1990, 34$35,46,107,117-18,130,174-77)$, Dostoevsky's characters are active and free persons, ${ }^{20}$ and the aesthetics of their literary form is dominated by their concrete first-person perspective, not by the view from outside.

As Bakhtin's working notes and drafts from the second half of the 1930s (some of which have only been published quite recently) show, this idea of the image of a free person-a creator, an initiator, an activist (deiatel'), a person shown within the world that he is changing (Bakhtin 2012, 226, 261-64, 278, 325, 332, 571, 578, 586, 640; Bakhtin 1981b, 38)-is the true center and prime mover of Bakhtin's theory of the novel. Bakhtin tries to trace the historical processes in which such an image was forged, and he is especially interested in the ways in which such an image can be expressed in space and time.

This is precisely the context in which Bakhtin's notion of carnival eventually emerges. To cut a long story short, the aesthetics of carnival offers Bakhtin a neat solution to the problem of creating an image of a free, creative individual: An image of a deed is an image of the world that deed constitutes; the image of a free person is an image of the world as that person experiences and changes it. ${ }^{21}$

If you consider carnival imagery from this perspective, things start falling into place. Bakhtin repeatedly stresses in his descriptions of carnival elements that correspond to his accounts, in his early works, of the world of the deed, the world as it is for me. The grotesque body is always shown in its interaction with the world and with other bodies, but never as a well-defined shape within the world (Bakhtin 2008, 647). The aesthetic principle behind this approach to the body is determined by how a body is experienced from within.

\footnotetext{
${ }^{18}$ In fact, we have evidence that Bakhtin was already working on a book about Dostoevsky in 1921/2 (Emerson 1984, xxix, xxxix).

${ }^{19}$ Contrast this, again, with Groys' claim that a polyphonic novel has no author. This reading rolls back precisely the authorial agency Bakhtin now credits Dostoevsky with.

${ }^{20}$ The freedom of Dostoevsky's characters receives comparatively little emphasis in Bakhtin scholarship, so it is worth noting that the very first thing Bakhtin has to say about Dostoevsky's innovative form of authorship in his book is precisely that his characters are free: "Dostoevsky, like Goethe's Prometheus, creates not voiceless slaves (as does Zeus), but free people, capable of standing alongside their creator, capable of not agreeing with him and even of rebelling against him" (Bakhtin 1984a, 6; italics in the original).

${ }^{21}$ This principle is already evident in Bakhtin's (mostly lost) study of Goethe's Bildungsroman (Bakhtin 1986c; Bakhtin 2012, 180-

335), which precedes his work on carnival, but carnival offers Bakhtin a more comprehensive and historically grounded way of putting it to use.
} 
The world of Rabelais' novel, and of carnivalesque literature more generally, exists within the individual's "zone of contact" (Bakhtin 2008, 626; Bakhtin 2014, 524), and is thoroughly evaluated (Rabelais has no "neutral words and expressions"-Bakhtin 1984b, 420). This is not a world of general concepts, but of concrete actions and experiences, precisely in the sense Bakhtin speaks of in Toward a Philosophy of the Act. A passage from Bakhtin's recently published draft notebooks for his book on Rabelais is very telling in this respect:

An expansion of purview ${ }^{22}$ (of the spatial order), but there are no typifying generalizations. There are no chasms between the singular and the general. All abstractly-mathematical, irrational, and imaginary quantities are absent. Sharp contrasts with the Cartesian and Newtonian world. The general (the typical, functional, mathematically regular) has not yet begun to play a leading role in the model of the world. The movement followed not from the singularly particular to the general and typical, but from the singularly particular to the cosmic (which is also individual), from the small to the larger and largest. Hence the importance of lists and naming (where now we have a generalization, Rabelais had a list of all possible things and actions); a collective, in which every member can be named (Bakhtin 2008, 646).

So what, then, of the features Groys emphasizes in his reading of Bakhtin as reflecting a "belief in the ultimate truth of totalitarianism"? On one level, the aesthetics of carnival does not respect the contours of the individual human body. Grotesque imagery depicts bodies fused with one another and with the world, in the process of change and transformation. This may be one reason Groys claims that Bakhtin is against individuality (though Groys does not make this particular link explicit). But when we examine this feature of Bakhtin's aesthetics in its philosophical context, it turns out to reflect an expression of individuality in aesthetic form, not its erasure. The grotesque body's contours do not coalesce into a stable form because this body represents a body felt from within, and it represents a body felt from within to better depict the free, creative, acting, and interacting individual, not just her passive outward shape. ${ }^{23}$

Groys ascribes to Bakhtin the desire to denigrate the individual and dissolve her in the greater whole of the people, and the even greater whole of the world. But when we read Bakhtin in context, we realize that the world here is the individual's world. And as for the people, and the "ancestral body", Groys neglects to mention the main function this concept plays in Bakhtin's book: This bodily whole holds out the promise of immortality to the individual (Bakhtin 1984b, 322, 367). With this in mind, we can place this Bakhtinian notion in a sequence with other expressions of the same idea in his writings. It corresponds to his claim in "Author and Hero" that the soul (my mind as perceived by others), but not the spirit (my acting self from within), is immortal (Bakhtin 1990, 100-101). It also corresponds to Bakhtin's famous claim, in his latest notes, that in the endless dialogue in "major time" (bol'shoe vremia), personal meanings never die (Bakhtin 1986e, 170). In other words, this notion is one of several ways, in which the other, and ultimately God, makes a slightly disguised appearance in Bakhtin's book on Rabelais, and other works dealing with carnival. ${ }^{24}$

If we now come back to the violent treatment Rabelais subjects some of his characters to, we can notice another layer of meaning it acquires within Bakhtin's architectonics. In Bakhtin's analysis of

\footnotetext{
${ }_{23}^{22}$ Krugozor; this term was rendered as "horizon" in the published translations of Bakhtin's early works.

${ }^{23}$ Seen this way, the grotesque body has a lot in common, on Bakhtin's (and partly Voloshinov's) account, with another material expression of the person-language. Like the word, the grotesque body is "half someone else's" (poluchuzhoe; Bakhtin 1981a, 293). I make it my own, express my voice through it, by modulating, intonng, evaluating the words/bodies of others.

${ }^{24}$ I discuss some of the other forms the Other assumes in these works in Sandler (2016).
} 
Rabelais, this violence, and more generally, all forms of invective, is one pole of an ambivalent evaluation (combining invective and praise). Bakhtin's analysis of Shakespearian tragedy (Bakhtin 2014) allows for a certain degree of separation between the two poles of this ambivalent attitude, and also pinpoints a target for invective and violence (remember, we are talking about tragedy) that he does not name when discussing Rabelais.

Analyzing Macbeth, Bakhtin finds behind the story of a tyrant and usurper a deeper level, at which Macbeth exemplifies the tragedy of (political) power as such (not quite an endorsement of totalitarianism, I should note). And then there is a deeper level still, where Macbeth exemplifies the tragedy of "every self-asserting life" (Bakhtin 2014, 527), where "self-asserting" means refusing to accept its limits in time, its eventual replacement by a younger generation, seeking immortality through itself, not others. Such individual self-assertion-when taken to its logical conclusion-leads to murder, to the murder of one's parents and children. Such claims to power and immortality are "punished" by Shakespeare with a tragic end, by Rabelais with a thorough beating, by the carnival crowd with a "dethroning".

But recall that the world of carnival imagery is a world experienced from within, so this "punishment" (or better, refutation) originates in the individual herself. It is, in fact, a later development of what early Bakhtin called "absolute self-exclusion"-my exclusion from the world constituted by my deeds, which, at the same time also "the sense of all Christian morality" and "the starting point for altruistic morality" (Bakhtin 1993, 75).

This, finally, leads us to one truly valuable insight that Groys offers us at the very end of his article. All those dismembered bodies in Rabelais' novel are, in a sense, self-dismemberments. Groys correctly identifies the philosophical precedents Bakhtin is following here: Nietzsche's Birth of Tragedy, partly mediated through the writings of Russian symbolists. Yes, this is precisely, in Groys' words, "ritualistic Dionysian self-destruction". No, it does not reflect Bakhtin's attempt to aesthetically justify his own persecution (as we just saw, there are equivalents of this self-dismemberment in Bakhtin's work that long predate his 1929 arrest), and there is one more detail that Groys leaves out of his retelling of the story: In the end, Dionysus is reborn.

\section{Conclusion}

Boris Groys' contrarian reading of Bakhtin as an apologist for totalitarianism is-not to put too fine a point on it-wrong. Nevertheless, it has been a useful exercise. It offered an effective refutation of other simplistic political readings of Bakhtin (a popular pastime for some) and it opened a door to a deeper exploration of the complex, sometimes difficult, philosophy of Mikhail Bakhtin.

\section{References}

Bakhtin, Mikhail Mikhailovich. 1981a. "Discourse in the Novel." In The Dialogic Imagination: Four Essays, edited by Michael Holquist, translated by Caryl Emerson and Michael Holquist, 259-422. Austin: University of Texas Press.

1981b. "Epic and Novel." In The Dialogic Imagination: Four Essays, edited by Michael Holquist, translated by Caryl Emerson and Michael Holquist, 3-40.

1981c. "Forms of Time and of the Chronotope in the Novel." In The Dialogic Imagination: Four Essays, edited by Michael Holquist, translated by Caryl Emerson and Michael Holquist, 84-258. Austin: University of Texas Press. 
— 1981d. The Dialogic Imagination: Four Essays. Edited by Michael Holquist. Translated by Caryl Emerson and Michael Holquist. Austin: University of Texas Press.

_- 1984a. Problems of Dostoevsky's Poetics. Edited and translated by Caryl Emerson. Minneapolis: University of Minnesota Press.

1984b. Rabelais and His World. Translated by Hélène Iswolsky. Bloomington and Indianapolis: Indiana University Press.

1986a. “From Notes Made in 1970-71." In Speech Genres and Other Late Essays, edited by Caryl Emerson and Michael Holquist, translated by Vern W. McGee, 132-58. Austin: University of Texas Press.

_ 1986b. "Response to a Question from the Novy Mir Editorial Staff." In Speech Genres and Other Late Essays, edited by Caryl Emerson and Michael Holquist, translated by Vern W. Mcgee, 1-7. Austin: University of Texas Press.

1986c. "The Bildungsroman and Its Significance in the History of Realism (toward a Historical Typology of the Novel)." In Speech Genres and Other Late Essays, edited by Caryl Emerson and Michael Holquist, translated by Vern W. Mcgee, 10-59. Austin: University of Texas Press.

1986d. "The Problem of the Text in Linguistics, Philology, and the Human Sciences: An Experiment in Philosophical Analysis." In Speech Genres and Other Late Essays, edited by Caryl Emerson and Michael Holquist, translated by Vern W. Mcgee, 103-31. Austin: University of Texas Press.

1986e. "Toward a Methodology for the Human Sciences." In Speech Genres and Other Late Essays, edited by Caryl Emerson and Michael Holquist, translated by Vern W. McGee, 159-72. Austin: University of Texas Press.

1990. "Author and Hero in Aesthetic Activity." In Art and Answerability: Early Philosophical Essays, edited by Michael Holquist and Vadim Liapunov, translated by Vadim Liapunov, 4-256. Austin: University of Texas Press.

1993. Toward a Philosophy of the Act. Edited by Michael Holquist and Vadim Liapunov. Translated by Vadim Liapunov. Austin: University of Texas Press.

1996. Sobranie sochinenij. T. 5. Raboty 1940-kh - nachala 1960-kh godov. Edited by Sergey Georgievich Bocharov and Liudmila Archirovna Gogotishvili. Moscow: Russkie slovari.

2001. “M. M. Bakhtin's Lectures and Comments from 1924-1925: From the Notebooks of L. V. Pumpiansky." In Bakhtin and Religion: A Feeling for Faith, edited by Susan M. Felch and Paul J. Contino, 205-37. Evanston, IL: Northwestern University Press.

2002. Sobranie sochinenij. T. 6. "Problemy poetiki Dostoevskogo", 1963. Raboty 1960-kh-1970kh godov. Edited by Sergei Georgievich Bocharov and Liudmila Archirovna Gogotishvili. Moscow: Russkie slovari.

—_. 2008. Sobranie sochinenij. T. 4(1). "Fransua Rable v istorii realizma" (1940 g.). Materialy k knige o rable (1930-1950-e gg.). Kommentarii i prilozheniia. Edited by Irina L'vovna Popova. Moscow: Jazyki slavianskikh kul'tur.

2012. Sobranie sochinenij. T. 3. Teoriia romana (1930-1961 gg.). Edited by Sergey Georgievich Bocharov and Vadim Valer'janovich Kozhinov. Moscow: Jazyki slavianskikh kul'tur. 
—_. 2014. "Bakhtin on Shakespeare: Excerpt from 'Additions and Changes to Rabelais." Translated by Sergeiy Sandler. PMLA 129 (3): 522-37. doi:10.1632/pmla.2014.129.3.522.

Barthes, Roland. 1977. "The Death of the Author." In Image - Music - Text, translated by Stephen Heath, 142-48. London: Fontana Press.

Coates, Ruth. 1998. Christianity in Bakhtin: God and the Exiled Author. Cambridge: Cambridge University Press.

Descartes, Rene. 1996. Meditatoins on First Philosophy. Edited and translated by John Cottingham. Cambridge: Cambridge University Press.

Emerson, Caryl. 1984. Editor's preface to Problems of Dostoevsky's Poetics, by Mikhail Mikhailovich Bakhtin, xxix-xliii. Minneapolis: University of Minnesota Press.

- 2000. "The next Hundred Years of Mikhail Bakhtin (the View from the Classroom)." Rhetoric Review 19 (1-2): 12-27. doi:10.1080/07350190009359275.

Erdinast-Vulcan, Daphna. 2013. Between Philosophy and Literature: Bakhtin and the Question of the Subject. Stanford, CA: Stanford University Press.

Erdinast-Vulcan, Daphna, and Sergeiy Sandler. 2015. "Bakhtin and His Circle." In Theoretical Schools and Circles in the Twenieth-Century Humanities: Literary Theory, History, Philosophy, edited by Marina Grishakova and Silvi Salupere, 23-40. New York and London: Routledge.

Foucault, Michel. 1988. "What Is an Author." In Modern Criticism and Theory: A Reader, edited by David Lodge, translated by Joseph V. Harari, 197-210. London and New York: Longman.

Fryszman, Alex. 1996. "Kierkegaard and Dostoyevsky Seen through Bakhtin's Prism." Kierkegaardiana 18: 100-125.

Gogotishvili, Liudmila Archirovna. 1996. Commentary to Sobranie Sochinenij, by Mikhail Mikhailovich Bakhtin, edited by Sergei Georgievich Bocharov and Liudmila Archirovna Gogotishvili, 5:535658. Moscow: Russkie slovari.

Kierkegaard, Søren. 1992. Concluding Unscientific Postscript to Philosophical Fragments. Translated by Howard V. Hong and Edna H. Hong. Princeton, NJ: Princeton University Press.

Kristeva, Julia. 1986. "Word, Dialogue and Novel." In The Kristeva Reader, edited by Toril Moi, translated by Alice Jardine, Thomas Gora, and Leon S. Roudies, 34-61. New York: Columbia University Press.

Morson, Gary Saul, and Caryl Emerson. 1990. Mikhail Bakhtin: Creation of a Prosaics. Stanford, CA: Stanford University Press.

Nikulin, Dmitri. 2011. "The Man at the Mirror (Dialogue with Oneself)." Iris. European Journal of Philosophy and Public Debate 3 (5): 61-79.

http://www.fupress.net/index.php/iris/article/view/10148.

Sandler, Sergeiy. 2011. "Kierkegaard and Bakhtin's Philosophical Motivation." Paper presented at The XIV International Mikhail Bakhtin Conference, University of Bologna, July 2011. http://ssrn.com/abstract=2045694.

__ 2012a. "Bakhtin and the Kierkegaardian Revolution." SSRN Electronic Journal. doi:10.2139/ssrn.2558247. 
__ 2012b. "Whose Words Are These Anyway?" In Dialogues with Bakhtinian Theory, edited by Mykola Polyuha, Clive Thomson, and Anthony Wall, 227-42. London, Ontario: Mestengo Press.

__ 2013. "Language and Philosophical Anthropology in the Work of Mikhail Bakhtin and the Bakhtin Circle." Rivista Italiana Di Filosofia Del Linguaggio 7 (2): 152-65. doi:10.4396/20130711.

_- 2015. "A Strange Kind of Kantian: Bakhtin's Reinterpretation of Kant and the Marburg School." Studies in East European Thought 67 (3-4): 165-82. doi:10.1007/s11212-015-9237-2.

__ 2016. "Tema karnavala v kontekste filosofii M. M. Bakhtina." Studia Litterarum 1 (3-4): 10-28. doi:10.22455/2500-4247-2016-1-3-4-10-28.

Schittsova, Tatiana Valer'evna. 1999. K istokam ekzistentsial'noi ontologii: Paskal', Kirkegor, Bakhtin. Minsk: Propilei.

Todorov, Tzvetan. 1984. Mikhail Bakhtin: The Dialogical Principle. Translated by Wlad Godzich. Minneapolis: University of Minnesota Press.

Wall, Anthony. 1998. “A Broken Thinker.” The South Atlantic Quarterly 97 (3/4): 669-98.

\section{(c)) EY}

New articles in this journal are licensed under a Creative Commons Attribution 4.0 United States License.

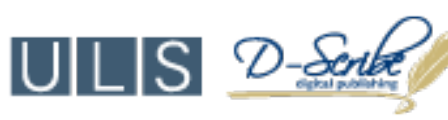

This journal is published by the University Library System, University of Pittsburgh as part of its D-Scribe Digital Publishing Program and is cosponsored by the University of Pittsburgh Press. 